\title{
Potensi Nutrisi Tepung Azolla microphylla dalam Memperbaiki Performan Itik Manila (Cairina moschata)
}

\author{
R. Dewanti \\ Jurusan Peternakan, Fakultas Pertanian, Universitas Sebelas Maret \\ Jl. Ir. Sutami 36 A, Kentingan, Surakarta \\ Email:Dewa_proter@yahoo.com
}

\section{INTISARI}

Penelitian ini bertujuan untuk mengetahui pengaruh penggunaan tepung Azolla microphylla dalam ransum terhadap performan itik manila dan mengetahui tingkat pemberian tepung azolla yang paling optimal. Penelitian dilaksanakan di kandang unggas ex-farm Jatikuwung Jurusan Peternakan Fakultas Pertanian UNS mulai 22 Juni 2007 sampai 25 Agustus 2007. Penelitian menggunakan 100 ekor itik manila betina yang ditempatkan dalam kandang litter secara acak. Percobaan menggunakan Rancangan Acak Lengkap (RAL) pola searah dengan empat perlakuan dan lima ulangan.

Perlakuan yang diberikan adalah: Ransum $+0 \%$ tepung azolla (P0); Ransum $+5 \%$ tepung azolla (P1); Ransum $+10 \%$ tepung azolla (P2); Ransum $+15 \%$ tepung azolla (P3). Peubah yang diamati adalah konsumsi pakan, pertambahan bobot badan, konversi pakan dan efisiensi pakan.

Hasil penelitian menunjukkan bahwa tingkat pemberian tepung azolla ke dalam pakan memberikan pengaruh yang sangat nyata terhadap pertambahan bobot badan, serta tidak berpengaruh terhadap konsumsi, konversi dan efisiensi pakan. Ransum dengan $10 \%$ tepung azolla (P2) menghasilkan pertambahan bobot badan terbaik (23,75 gram/ekor/hari) yang berbeda sangat nyata dari P0 (21,07 gram/ekor/hari). Hasil penelitian dapat disimpulkan bahwa ransum $+10 \%$ tepung azolla $(\mathrm{P} 2)$ memberikan hasil yang terbaik.

Kata kunci: tepung Azolla microphylla, performan, itik manila

\section{PENDAHULUAN}

Kebutuhan masyarakat Indonesia akan protein hewani semakin meningkat sejalan dengan meningkatnya keadaan ekonomi, kesadaran gizi, kesehatan serta pertambahan jumlah penduduk. Kebutuhan ini harus diimbangi dengan peningkatan produkproduk hasil peternakan sebagai bahan pangan bergizi dan sumber protein hewani. Salah satu usaha untuk dapat memenuhi kebutuhan protein hewani asal ternak sebesar 4,5 g perkapita perhari adalah dengan mencari terobosan-terobosan baru untuk mengembangkan usaha ternak yang dapat menghasilkan sumber protein hewani, mudah dalam pengelolaannya dan dapat diusahakan oleh setiap keluarga. Aneka ternak unggas dapat dijadikan komoditas penunjang, salah satunya itik manila (Muljowati, 1998). Itik manila merupakan komoditas ternak yang mempunyai prospek cukup baik dalam meningkatkan tambahan pendapatan petani (Bintang, 2000).

Menurut Leclercq dan Carville (1985), daging itik manila di negara Eropa lebih disukai dibandingkan itik Peking, disebabkan kandungan lemaknya lebih rendah dan bagian yang dapat dimakan lebih banyak. Perkembangan ternak itik, khususnya itik manila belum sepesat perkembangan ternak ayam petelur dan ayam pedaging. Pemeliharaan itik manila masih bersifat tradisional dan sebagai usaha 
sambilan sehingga dalam pemeliharaannya belum memperhatikan faktor-faktor bibit, pakan dan pengendalian penyakit. (Widodo et al., 1992). Itik manila belum mendapatkan perhatian yang serius, sehingga andilnya secara langsung dalam penyediaan sumber protein hewani di Indonesia belum dapat diandalkan (Bintang, 2000). Itik manila secara genetik memiliki kemampuan sebagai unggas penghasil daging.

Peranan itik manila dalam penyediaan protein hewani bagi masyarakat luas belum seperti ayam buras dan itik petelur, meskipun di beberapa negara ternak ini sudah terbukti dapat memberikan andil yang besar dalam perkembangan perunggasan (Stevens dan Sauveur, 1985; Tai, 1985). Pada umumnya peternak memelihara itik manila di pedesaan bertujuan untuk menghasilkan daging disamping sebagai tabungan serta kesenangan (Widodo et al., 1992; Basuno dan Abdelsamie, 1986), dan digunakan dalam penetasan telur-telur itik (Blakely dan Bade,1998; Srigandono, 2000).

Pakan menduduki urutan terbesar dari semua biaya produksi yaitu sekitar 70 sampai $80 \%$, oleh karena itu diperlukan pakan alternatif untuk memanfaatkan bahanbahan non konvensional yang murah, bergizi dan memperbaiki pertumbuhan. Bahan pakan yang potensial salah satunya adalah Azolla. Azolla mudah dibudidayakan sehingga harganya murah. Kandungan PKnya tidak setinggi bungkil kedelai, namun azolla mempunyai potensi besar sebagai bahan pakan untuk mengurangi pemakaian bungkil kedelai dalam ransum itik.

Azolla adalah sejenis tanaman air yang mampu menambat nitrogen dari udara karena bersimbiosis dengan satu jenis ganggang biru Anabaena azollae yang telah berhasil digunakan dalam bidang pertanian sebagai pupuk hijau (Abidin,1982 disitasi Surisdiarto dan Koentjoko, 1999). Pujaningsih et al. (1997) disitasi oleh Surisdiarto dan Koentjoko (1999) menyatakan bahwa susunan gizi tepung Azolla micropylla adalah $24,49 \%$ protein kasar (PK), 2\% (LK), 11,03\% (SK), 1,52\% kalsium $(\mathrm{Ca}), 0,96 \%$ pospor $(\mathrm{P})$ dan 1950 kkal/kg Metabolized Energy (ME).

Penelitian ini diharapkan dapat memberikan motivasi kepada peternak untuk dapat mengembangkan itik manila dengan pakan yang lebih murah, sehingga usaha yang dikelolanya akan berorientasi pada pasar dan profit.

\section{MATERI DAN METODE}

Penelitian ini dilaksanakan di kandang percobaan unggas Jatikuwung, Jurusan Peternakan Fakultas Pertanian UNS Surakarta mulai 22 Juni 2007 sampai 25 Agustus 2007. Penelitian ini menggunakan 100 ekor anak itik manila betina dan kandang dan perlengkapannya Peralatan lainnya meliputi timbangan merk Five Goats kapasitas lima kilogram kepekaan dua puluh gram, timbangan kapasitas dua kilogram kepekaan sepuluh gram, timbangan digital kapasitas $410 \mathrm{~g}$ kepekaan 0,001 dan termometer.

Tabel 1. Kebutuhan nutrien itik manila*

\begin{tabular}{ccccc}
\hline \hline \multirow{2}{*}{$\begin{array}{c}\text { Umur } \\
\text { (minggu })\end{array}$} & $\begin{array}{c}\text { Zat nutrisi } \\
(\text { Kkal/kg) }\end{array}$ & PK (\%) & Ca (\%) & P (\%) \\
\cline { 2 - 4 } & 2800 & 23,00 & 0,90 & 0,45 \\
$0-2$ & 2800 & 20,00 & 0,90 & 0,45 \\
$4-4$ & 2800 & 18,00 & 0,80 & 0,45 \\
$6-6$ & 2800 & 18,00 & 0,80 & 0,45 \\
$8-10$ & 2800 & 15,00 & 0,80 & 0,45 \\
\hline
\end{tabular}

Keterangan : ${ }^{*}$ Persyaratan gizi yang baku belum tersedia

Sumber : Hardjosworo dan Rukmiasih (2000) 
Ransum terdiri dari jagung kuning, bekatul, menir, bungkil kedelai, tepung ikan, premik, mineral dan tepung azolla microphylla. Ransum disusun isoprotein. Ransum perlakuan meliputi : P0 (ransum + $0 \%$ tepung azolla), P1 (Ransum $+5 \%$ tepung azoola), P2 (Ransum $+10 \%$ tepung azolla), P3 (Ransum $+15 \%$ tepung azolla). Peubah yang diambil meliputi konsumsi pakan, pertambahan bobot badan, konversi pakan, dan efisiensi pakan. Analisis data menggunakan Rancangan Acak Lengkap
Pola Searah, dan apabila berbeda nyata dilanjutkan dengan Duncan Multiple Range Test (DMRT).

\section{HASIL DAN PEMBAHASAN}

\section{Konsumsi Pakan}

Rerata konsumsi pakan itik manila untuk masing-masing perlakuan selama penelitian disajikan pada Tabel 4.

Tabel 4. Rerata Konsumsi Pakan Itik Manila Selama Penelitian (g/ekor/hari)

\begin{tabular}{ccccc}
\hline \hline & \multicolumn{4}{c}{ Perlakuan } \\
\cline { 2 - 5 } Ulangan & P0 & P1 & P2 & P3 \\
\hline R1 & 180,21 & 156,14 & 191,11 & 105,25 \\
R2 & 169,55 & 146,36 & 190,52 & 164,50 \\
R3 & 137,50 & 160,23 & 188,49 & 182,11 \\
R4 & 99,18 & 110,13 & 190,56 & 127,13 \\
R5 & 135,39 & 200,57 & 198,34 & 193,11 \\
\hline Rerata & 144,37 & 154,69 & 191,80 & 154,42 \\
\hline Jumlah & 721,83 & 773,43 & 959,02 & 772,10 \\
\hline
\end{tabular}

Berdasarkan Tabel 4 dapat dilihat rerata konsumsi pakan hasil penelitian untuk perlakuan P0, P1, P2, P3 berturut-turut adalah 144,$37 ; 154,69 ; 191,80 ; 154,42 \mathrm{~g}$. Hasil analisis variansi menunjukkan bahwa rerata konsumsi pakan antar perlakuan tidak berbeda nyata. Hal ini menunjukkan bahwa persentase pemberian tepung azolla yang berbeda tidak menyebabkan perbedaan pada konsumsi pakan itik manila. Rerata konsumsi pakan antar perlakuan tidak berbeda nyata dikarenakan sistem pemeliharaan, keadaan lingkungan, jenis itik dan umur dalam penelitian ini sama. Hal ini didukung Srigandono (1991), yang menyatakan bahwa kuantitas konsumsi pakan pada itik ditentukan oleh berbagai faktor diantaranya adalah sistem pemeliharaan, keadaan lingkungan maupun jenis itiknya sendiri.

Ewing (1963) yang disitasi Prabowo (2000), menyatakan bahwa unggas dengan umur yang sama mempunyai kemampuan mengkonsumsi pakan yang sama karena kemampuan saluran pencernaan unggas terutama tembolok dalam menampung pakan relatif sama. Umur itik dalam penelitian ini sama sehingga konsumsi pakan tidak berbeda nyata. Ditambahkan Wahju (1992), bahwa konsumsi pakan juga dipengaruhi oleh kecepatan pertumbuhan. Unggas dengan umur yang sama, mempunyai kecepatan pertumbuhan yang relatif sama, sehingga konsumsi pakanpun tidak berbeda.

\section{Pertambahan Bobot Badan}

Rerata pertambahan bobot badan itik manila untuk masing-masing perlakuan selama penelitian disajikan pada Tabel 5 .

Tabel 5 menunjukkan bahwa rerata pertambahan bobot badan untuk P0, P1, P2, dan P3 berturut-turut adalah 21,07; 22,86; 23,75; 23,21 g/ekor/hari. Hasil analisis variansi menunjukkan bahwa rerata pertambahan bobot badan antar perlakuan berbeda sangat nyata $(\mathrm{P}<0,01)$. Hal ini menunjukkan tepung Azolla microphylla sangat berpengaruh terhadap pertambahan bobot badan. 
Perlakuan P0 memberikan hasil yang berbeda sangat nyata dengan P2 dan P3. Perlakuan P0, P2, dan P3 mempunyai konsumsi pakan yang tidak berbeda namun menghasilkan pertumbuhan atau pertambahan bobot badan yang berbeda. Hal ini bisa disebabkan dari ransum P2 dan P3 yang mengandung tepung azolla. Tepung azolla mempunyai kandungan asam amino baik essensial maupun nonessensial yang cukup baik. Menurut Sudaro dan Siriwa (2001) asam amino essensial merupakan asam amino yang tidak dapat disintesis itik sehingga perlu disediakan dalam ransum. Sedangkan asam amino nonessenaial sebagian kecil tidak dapat disintesis tubuh dalam waktu cepat untuk pertumbuhan sehingga perlu ditambahkan dalam ransum.

Tabel 5. Rerata Pertambahan Bobot Badan Itik Manila Selama Penelitian (g/ekor/hari)

\begin{tabular}{crrrr}
\hline \hline & \multicolumn{4}{c}{ Perlakuan } \\
\cline { 2 - 5 } Ulangan & P0 & P1 & P2 & P3 \\
\hline R1 & 19,50 & 21,35 & 23,67 & 22,91 \\
R2 & 20,45 & 23,50 & 24,71 & 23,90 \\
R3 & 22,01 & 23,34 & 23,89 & 22,20 \\
R4 & 21,23 & 21,42 & 22,54 & 24,30 \\
R5 & 22,16 & 24,69 & 23,94 & 22,74 \\
\hline Rerata & $21,07^{\mathrm{A}}$ & $22,86^{\mathrm{B}}$ & $23,75^{\mathrm{B}}$ & $23,21^{\mathrm{B}}$ \\
\hline Jumlah & 105,35 & 114,30 & 118,75 & 116,05 \\
\hline
\end{tabular}

Keterangan: ${ }^{\mathrm{AB}}$ Rerata yang diikuti superskrip yang berbeda menunjukkan berbeda sangat nyata pada taraf $1 \%$ dengan uji jarak berganda Duncan $(\mathrm{P}<0,01)$

\section{Konversi Pakan}

Rerata konversi pakan itik manila untuk masing-masing perlakuan selama penelitian disajikan pada Tabel 6.

Berdasarkan Tabel 6 dapat dilihat rerata konversi pakan hasil penelitian untuk perlakuan P0, P1, P2, dan P3 berturut-turut adalah 6,$91 ; 6,73 ; 8,08$; 6,68 . Hasil analisis variansi menunjukkan bahwa rerata konversi pakan antar perlakuan tidak berbeda nyata. Hasil ini memberikan gambaran bahwa kemampuan itik manila dalam memanfaatkan pakan yang di konsumsi untuk pertumbuhan dengan persentase tepung azolla yang berbeda adalah sama. Itik manila yang diberi pakan P0 (ransum $+0 \%$ azolla); P1 (ransum $+5 \%$ azolla); P2 (ransum $+10 \%$ azolla);P3 (ransum $+15 \%$ azolla) relatif mampu memanfaatkan makanan yang sama ditandai dengan nilai konversi pakan yang relatif sama pula.

Tabel 6. Rerata konversi pakan itik manila selama penelitian

\begin{tabular}{ccccc}
\hline \hline & \multicolumn{4}{c}{ Perlakuan } \\
\cline { 2 - 5 } Ulangan & P0 & P1 & P2 & P3 \\
\hline R1 & 9,24 & 7,31 & 8,07 & 4,59 \\
R2 & 8,29 & 6,23 & 7,71 & 6,88 \\
R3 & 6,25 & 6,86 & 7,89 & 8,20 \\
R4 & 4,67 & 5,14 & 8,45 & 5,23 \\
R5 & 6,11 & 8,12 & 8,28 & 8,49 \\
\hline Rerata & 6,91 & 6,73 & 8,08 & 6,68 \\
\hline Jumlah & 34,56 & 33,66 & 40,40 & 33,39 \\
\hline
\end{tabular}


Menurut Anggorodi (1995) bahwa daya cerna ternak yang bersangkutan akan mempengaruhi besar kecilnya angka konversi pakan. Irawan (1996) menambahkan bahwa konversi pakan dipengaruhi oleh beberapa faktor antara lain jenis ternak, keadaan lingkungan, jenis kelamin dan umur. Jenis ternak, keadaan kandang, jenis kelamin dan umur pada penelitian ini sama, sehingga konversi pakannyapun tidak berbeda. Itik manila dengan umur yang sama relatif memiliki kemampuan yang mencerna yang sama sehingga konversi pakannya tidak berbeda.

\section{Efisiensi Pakan}

Efisiensi pakan untuk P0, P1, P2, P3 masing-masing adalah 0,$15 ; 0,15 ; 0,12$; 0,16 . Lebih jelasnya dapat dilihat pada Tabel 7. Berdasarkan analisis variansi menunjukkan bahwa penggunaan tepung Azolla microphylla dalam ransum itik manila betina sampai taraf $15 \%$ berpengaruh tidak nyata terhadap efisiensi pakan.

Tabel 7. Rerata Efisiensi Pakan

\begin{tabular}{ccccc}
\hline \hline & \multicolumn{4}{c}{ Perlakuan } \\
\cline { 2 - 5 } Ulangan & P0 & P1 & P2 & P3 \\
\hline R1 & 0,11 & 0,14 & 0,12 & 0,22 \\
R2 & 0,12 & 0,16 & 0,13 & 0,15 \\
R3 & 0,16 & 0,15 & 0,13 & 0,12 \\
R4 & 0,21 & 0,19 & 0,12 & 0,19 \\
R5 & 0,16 & 0,12 & 0,12 & 0,12 \\
\hline Rerata & 0,15 & 0,15 & 0,12 & 0,16 \\
\hline Jumlah & 0,77 & 0,76 & 0,62 & 0,79 \\
\hline
\end{tabular}

Efisiensi pakan merupakan besarnya bagian pakan yang dapat dirubah menjadi produk (daging atau telur). Efisiensi pakan sangat berhubungan dengan konversi pakan. Semakin rendah konversi pakan, maka efisiensi pakan semakin bagus. Begitu juga sebaliknya semakin besar konversi pakan maka efisiensi pakan semakin rendah atau buruk. Dari hasil penelitian ini konversi pakan cukup tinggi sehingga efisiensi pakanpun rendah. Hal ini disebabkan konsumsi pakan itik manila memang lebih tinggi apabila dibandingkan dengan ayam. Selain itu, cara makan itik manila inipun berbeda dari ayam. Gerakan makan ayam naik turun sehingga kemungkinan pakan tercecer kecil, sedangkan itik manila mempunyai gerakan maju mundur dan kebiasaan makanminum-makan-minum dan seterusnya, sehingga lebih boros dalam hal pakan.

\section{KESIMPULAN}

Penggunaan tepung Azolla microphylla sampai taraf $15 \%$ dalam ransum dapat meningkatkan pertambahan bobot badan tetapi tidak memperbaiki konsumsi, konversi dan efisiensi pakan itik manila betina. Ransum $+10 \%$ tep azolla memberikan hasil yang optimal

\section{DAFTAR PUSTAKA}

Anggorodi, R 1995. Nutrisi Aneka Ternak Unggas. PT Gramedia Pustaka Utama, Jakarta.

Bintang, I.A.K. 2000. Performans Anak Entog Dengan Berbagai Pola Pemeliharaan. Jurnal Peternakan dan Lingkungan. Fakultas Peternakan Universitas Andalas Kampus Limau Manis, Padang. 6(01): 47-51.

Hardjosworo, P dan Rukmiasih. 2000. Meningkatkan Produksi Daging Unggas. Cet 1. Penebar Swadaya, Jakarta. 
Irawan, A. 1996. Ayam-ayam Pedaging Unggul. CV Aneka Ilmu, Solo.

Laboratorium Mikrobiologi UGM, 1990. Azolla. Fakultas Pertanian. Universitas Gadjah Mada, Yogyakarta.

Leclercq dan Carville. 1985. Growth And Body Composition of Muscovy Ducks. In Duck Produktion Science And World Practice. D.J. Farrel and Stapleton P. (Ed). University of New England. 102-109.

Muljowati, S. 1998. Hubungan Antara Bobot Badan Dengan Kandungan Nutrien Itik Daging Itik Manila Yang Dipelihara Secara Tradisional. Majalah Ilmiah. UNSOED. No.2/th.xxiv Edisi Juni 1998:82.

National Research Council, 1971. Nutrient Requirements of Poultry. National Research Council. NAS. NRC. Publishing, Washington DC.

Prabowo, Y.S.E. 2000. Pengaruh Penambahan tepung remis dalam campuran ransum komersial dan dedak halus terhadap konsumsi ransum pertambahan bobot badan dan konversi ransum ayam kampung. Skripsi. Fakultas Peternakan UNDIP, Semarang.

Srigandono, B. 1991. Ilmu Unggas Air. Gadjah Mada University Press, Yogyakarta

Stevens, P. dan Sauveur. 1985. Duck Production and Management In France.In Duck Production Science and World Practices. D.J. Farrell and Stapleton P.(Ed). University of New England. Australia: 248-257.

Sudaro dan Siriwa, 2003. Ransum Ayam dan Itik. Penebar Swadaya, Jakarta.
Surisdiarto dan Koentjoko, 1999. Nilai nutrisi Protein Azolla microphylla pada ayam Pedaging Periode Awal. Jurnal Peternakan dan Lingkungan. Universitas Andalas, Padang. 5 (01): 13-20.

Rasidi, 1997. 302 Formulasi Pakan Lokal Alternatif untuk Unggas. Penebar Swadaya, Jakarta.

Rasyaf, M. $1989 . \quad$ Nutrisi dan Makanan untuk Bebek. Poultry Indonesia. 10(118) : 17.

1990. Bahan Makanan

Unggas di Indonesia. Kanisius, Yogyakarta.

. 1992. Pengelolaan Peternakan Unggas Pedaging Kalkun Bebek Angsa Puyuh Merpati. Kanisius, Yogyakarta. .1994. Makanan Ayam Broiler. Penerbit Kanisius, Yogyakarta. 2002. Beternak Ayam Pedaging. Penebar Swadaya, Jakarta.

Tai, C. 1985. Duck Production in Taiwan. In Duck Production Science and World Practices. D.J. Farrell and Stapleton P. (ed). University of New England, Australia. 364-371.

Wahju, J. 1992. Ilmu Nutrisi Unggas. Gadjah Mada University Press, Yogyakarta. 1997. Ilmu Nutrisi Unggas. Gadjah Mada University Press, Yogyakarta.

Widodo, E.; O. Sjofjan; Surisdiarto dan Koentjoko. 1992. Pengaruh Tingkat Protein dalam Pakan Terhadap Performans Itik Manila Periode Starter. Jurnal-Jurnal Ilmu Peternakan. Universitas Brawijaya, Malang. 7:47-56. 